\title{
eDNA metabarcoding for diet analyses of green sea turtles (Chelonia mydas)
}

\author{
Lucía Díaz-Abad $^{1,8} \cdot$ Natassia Bacco-Mannina $^{1} \cdot$ Fernando Miguel Madeira ${ }^{2} \cdot$ João Neiva $^{1} \cdot$ Tania Aires $^{1}$. \\ Ester A. Serrao ${ }^{1,3} \cdot$ Aissa Regalla $^{4}$ - Ana R. Patrício ${ }^{5,6} \cdot$ Pedro R. Frade $^{1,7}$ (i)
}

Received: 20 May 2021 / Accepted: 24 November 2021 / Published online: 29 December 2021

(c) The Author(s) 2021

\begin{abstract}
Understanding sea turtle diets can help conservation planning, but their trophic ecology is complex due to life history characteristics such as ontogenetic shifts and large foraging ranges. Studying sea turtle diet is challenging, particularly where ecological foraging observations are not possible. Here, we test a new minimally invasive method for the identification of diet items in sea turtles. We fingerprinted diet content using DNA from esophageal and cloacal swab samples by metabarcoding the 18S rRNA gene. This approach was tested on samples collected from green turtles (Chelonia mydas) from a juvenile foraging aggregation in the Bijagós archipelago in Guinea-Bissau. Esophagus samples $(n=6)$ exhibited a higher dietary richness ( $11 \pm 5$ amplicon sequence variants (ASVs) per sample; average \pm SD) than cloacal ones $(n=5 ; 8 \pm 2 \mathrm{ASVs})$. Overall, the diet was dominated by red macroalgae (Rhodophyta; $48.2 \pm 16.3 \%$ of all ASVs), with the main food item in the esophagus and cloaca being a red alga belonging to the Rhodymeniophycidae subclass ( $35.1 \pm 27.2 \%$ ), followed by diatoms (Bacillariophyceae; $7.5 \pm 7.3 \%$ ), which were presumably consumed incidentally. Seagrass and some invertebrates were also present. Feeding on red algae was corroborated by field observations and barcoding of food items available in the benthic habitat, validating the approach for identifying diet content. We conclude that identification of food items using metabarcoding of esophageal swabs is useful for a better understanding of the relationships between the feeding behavior of sea turtles and their environment.
\end{abstract}

Keywords DNA barcoding $\cdot$ Guinea-Bissau $\cdot$ Macrophytes $\cdot$ Green turtle $\cdot$ Feeding ecology $\cdot$ Marine biodiversity

\section{Introduction}

Effective planning of biodiversity conservation depends on a good understanding of the relationships between species or populations of interest and their environment (Bremner

Responsible Editor: L. Avens.

Pedro R. Frade

pedro.frade@nhm-wien.ac.at

1 CCMAR-Centre of Marine Sciences, CIMAR, University of Algarve, Faro, Portugal

2 cE3c Centre for Ecology, Evolution and Environmental Changes, Faculdade de Ciências da Universidade de Lisboa, Lisbon, Portugal

3 CIBIO/InBIO-Centro de Investigação em Biodiversidade e Recursos Genéticos, Vairão, Portugal

4 IBAP-Instituto da Biodiversidade e das Áreas Protegidas, Dr. Alfredo Simão da Silva, Bissau, Guinea-Bissau
2008). Identifying diet items of threatened species is important to understand food preference, the availability and quality of food in their habitats, and to account for trophic interactions when designing habitat protection (Hamann et al. 2010). Understanding the foraging ecology and diet composition of species that go through ontogenetic diet shifts (Carr 1987) and/or that have large foraging ranges

5 MARE-Marine and Environmental Sciences Centre, ISPA-Instituto Universitário, Lisbon, Portugal

6 Centre for Ecology and Conservation, College of Life and Environmental Sciences, University of Exeter, Exeter, UK

7 Natural History Museum Vienna, Vienna, Austria

8 IMBRSea, International Master of Science in Marine Biological Resources, IMBRSea Universities Consortium, Ghent, Belgium 
(Hazel et al. 2013) is challenging, often requiring invasive sampling. These challenges are very relevant for sea turtles, which are charismatic species of conservation concern (Arthur et al. 2008). The seven species of sea turtles are threatened by human exploitation and environmental change and are included in the IUCN Red list as critically endangered, endangered, vulnerable or data deficient. Despite the recovery of some major populations in the last decade following conservation efforts (Mazaris et al. 2017), many populations continue to face large-scale anthropogenic threats, namely degradation and loss of nesting and feeding habitats, incidental capture in fisheries, direct harvesting, plastic ingestion and climate change (Santidrián-Tomillo et al. 2015; Casale and Heppell 2016; Nelms et al. 2016; Summers et al. 2018; Patrício et al. 2021). Accumulated evidence emphasizes the importance of adopting conservation actions to protect key habitats such as nesting beaches and feeding grounds (Wallace et al. 2011; Godley et al. 2020).

Since it is very difficult to observe sea turtles feeding under completely natural conditions (Legler 1976), diet studies have traditionally relied on the direct observation of stomach contents (Williams et al. 2013; Brandis et al. 2014) and, in some cases, of what remains in fecal material (Bjorndal 1997). To assess green turtle (Chelonia mydas) diet using stomach contents, several studies have used stranded or bycaught (dead) turtles (Mortimer 1981; André et al. 2005; Howell et al. 2016; Howell and Shaver 2021). Although useful, this approach limits the sampling to a group of animals that may not be representative of the population (Levey and Martinez del Rio 2001). Another traditional approach is to conduct esophageal lavage, flushing out recently ingested food items (Holloway-Adkins and Hanisak 2017). This procedure requires appropriate training and is invasive, which can stress and harm the turtles (Legler 1977; Amarocho and Reina 2007). For coastal life stages, lavage is typically only appropriate for the herbivorous green turtle whose diet is dominated by soft food items. Stable isotope analysis has also been used as an indirect, less invasive method to infer the diet of sea turtles (e.g., Seminoff et al. 2006; Arthur et al. 2008; Shimada et al. 2014), but with low resolution, not allowing direct food species identification and quantification, and requiring information on the isotopic composition of putative diet items (Gannes et al. 1997; Post 2002; Burkholder et al. 2011). Some techniques used to assess the diet of sea turtles are summarized in Table S1.

Recently, feeding studies have been revolutionized by the onset of DNA metabarcoding (Taberlet et al. 2012). This approach has been used, for example, to characterize the gut microbiome of loggerhead sea turtles (Arizza et al. 2019) and to characterize the diet of a diverse range of other marine taxa (e.g., Albaina et al. 2016). The combination of DNA metabarcoding with less invasive wildlife sampling techniques, such as the use of swabs for digestive tract sample collection, enables species-level identification of diet items. In other organisms such as birds, cloacal swabs have already been used to successfully estimate species-specific diet composition (Williams and Athrey 2020; Bodawatta et al. 2020). Such specificity requires the use of genetic markers for which a reference databank of relevant sequences of potential diet items is available. The $18 \mathrm{~S}$ rRNA gene was shown to be particularly useful in barcoding marine macrophytes (Ortega et al. 2020), fish (Albaina et al. 2016) and marine invertebrates (Zhang et al. 2018), which are within the typical diet items of sea turtles (Bjorndal 1997).

Here, we aimed to tackle the difficulties in assessing sea turtle diets in the field by testing a new method for the identification of food items in the diet of sea turtles, based on esophageal and cloacal swab samples analyzed by metabarcoding of the 18S rRNA gene. To the best of our knowledge, no study has used metabarcoding of diet content on $C$. mydas, and this study contributes to a better understanding of the feeding behavior of the sea turtles. With this new method, we aim to identify eukaryotic DNA sequences from food items present in esophageal and cloacal samples. The method was tested using a juvenile foraging aggregation of green turtles from the western coast of Africa. We address two main objectives: (1) determining whether DNA metabarcoding with the 18S rRNA gene is useful to identify food items of sea turtles; and (2) comparing the information between esophageal and cloacal samples, to determine which sample type is better for a more complete diet assessment of green turtles (C. mydas).

\section{Materials and methods}

\section{Study sites and sampling}

Esophageal and cloacal swab samples were collected from juvenile green turtles (Chelonia mydas; sizes ranged from 36.5 to $48.1 \mathrm{~cm}$ of curved carapace length, with an average of $40.6 \mathrm{~cm} \pm 4.5 \mathrm{~cm} \mathrm{SD)} \mathrm{foraging} \mathrm{around} \mathrm{Unhocomo}$ and Unhocomozinho islands $\left(11^{\circ} 31^{\prime} \mathrm{N} ; 16^{\circ} 40^{\prime} \mathrm{W}\right.$, Fig. 1), located at the westernmost limit of the Bijagós Archipelago, Guinea-Bissau, West Africa. Sampling took place on 27 October 2019. Sea floor was mostly sandy with some rocky areas, covered by patches of green, red and brown algae, and sparse seagrass (Halodule sp., see description of benthic community below).

Green turtles were caught using one entanglement net $(800 \mathrm{~m}$ long, $4 \mathrm{~m}$ deep, $20 \mathrm{~cm}$ knot to knot mesh size), deployed from a pirogue (canoe), operated by local Bijagós fishermen, enclosing foraging sites for periods of $1 \mathrm{~h}$, under constant monitoring for entangled turtles. Captured turtles were brought onboard another vessel (anchored next to the net) and positioned comfortably, 


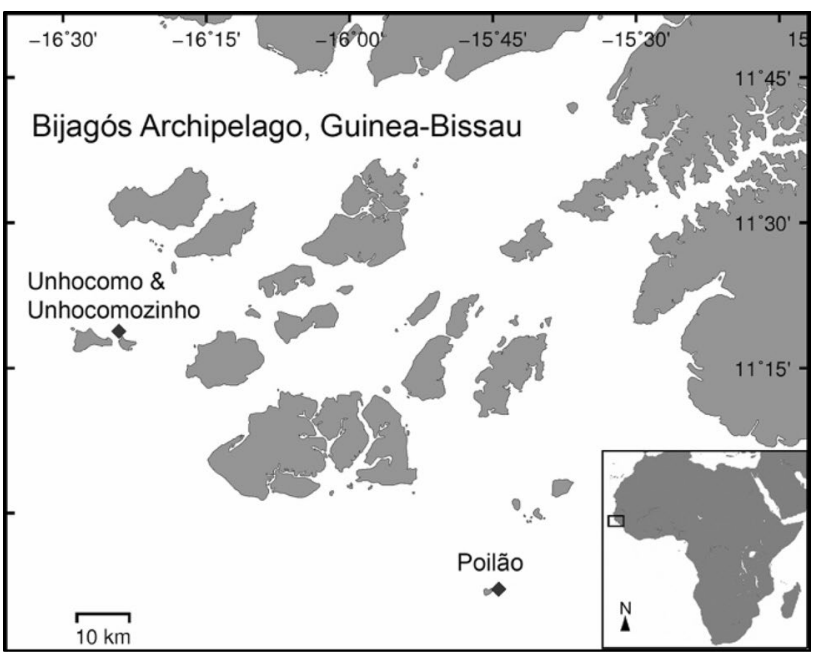

Fig. 1 Map of the study site: Poilão and Unhocomo islands in Guinea-Bissau, West Africa

with the plastron on a flat surface and front flippers held close to the body. Cloacal and esophageal swab sampling were performed as follows: for the esophageal swab, the mouth of the turtle was gently kept open and the esophageal entrance sampled as deep as possible using a $20 \mathrm{~cm}$ long sterile swab (making a gentle swirl 2-3 times) not touching any other parts of the turtle; for the cloacal swab, the opening of the cloaca was cleaned with a chlorhexidine wet gauze before inserting a smaller sterile swab $2 \mathrm{~cm}$ into the cloaca ( $2-3$ swirls as before). Gloves were used at all times and changed between individual turtles and also between collection of esophageal and cloacal samples within the same individual. Handling of turtles was kept to a minimum (max. 15 min per individual), to reduce their stress, and turtles were kept covered with a wet towel while onboard the research vessel. Swabs were stored in individual centrifuge tubes (esophagus swabs in $50 \mathrm{~mL}$ and cloaca swabs in $2 \mathrm{~mL}$ tubes) filled with $96 \%$ EtOH and kept at room temperature until stored at $2-5^{\circ} \mathrm{C}$ for a week and then at $-20^{\circ} \mathrm{C}$ at the CCMAR laboratory.

Additionally, digestive tract samples (intestines) from hatchlings were collected to be used as methodological control, since newly emerged hatchlings have not yet fed (Smith and Daniel 1946; Hughes 1974) and should thus be free of any foreign DNA indicative of food ingestion. Dissection of digestive tracts was only performed on recently dead hatchlings found on the beach in Poilão Island $\left(10^{\circ}\right.$ $52^{\prime} \mathrm{N} ; 15^{\circ} 43^{\prime} \mathrm{W}$, Fig. 1), a major rookery for green turtles in the Bijagós archipelago (Patrício et al. 2019). Swabbing was performed in intestines and swabs kept in $2 \mathrm{~mL}$ microcentrifuge tubes with $96 \% \mathrm{EtOH}$.

\section{DNA extraction and analysis of metabarcoding data}

Nucleic acid extraction was performed with the QIAGEN DNeasy PowerBiofilm kit, following manufacturer's instructions plus a few customized steps. A small portion of the cotton tip of the sampling swab $(30-100 \mathrm{mg}$ ) was initially rinsed in sterile water to remove $\mathrm{EtOH}$, then centrifuged at maximum speed and transferred to the bead tube. Bead tubes were incubated at $65^{\circ} \mathrm{C}$ for $30 \mathrm{~min}$ and then homogeneized in a TissueLyser for $3 \mathrm{~min}$ at 18,000 rpm.

DNA extracts were sent on dry-ice to MRDNA (Texas, USA) and a 133-bp fragment of the 18S rRNA gene was amplified using the primer set 18S_Euka02(V7) (forward: 5'-TTTGTCTGSTTAATTSCG-3'; reverse: 5'-CACAGA CCTGTTATTGC- $3^{\prime}$ ) as recommended by Ortega et al. (2020) and following standard conditions (Guardiola et al. 2015). Sequencing took place on an Illumina MiSeq platform using $2 \times 300$-bp paired-end technology. Demultiplexed reads were analyzed as single nucleotide variants using QIIME2 as described in Bolyen et al. (2019; Version 2019.7 https://qiime2.org). Forward and reverse primers were removed using FASTqProcessor (http://www.mrdna lab.com/mrdnafreesoftware/fastq-processor.html) and chimeric sequences were removed using DADA2 (phred $>35$; trimming $=10)($ Callahan et al. 2016). Sequences were grouped using DADA2 (Callahan et al. 2016) based on $100 \%$ sequence similarity, generating representative sequences subsequently referred to as amplicon sequence variants (ASVs). For taxonomic assignment, a naïve-Bayes classifier was trained on the SILVA v132 99\% database (Quast et al. 2013), with sequences limited to the V7 region of the 18S rRNA genes. Plastid-derived sequence reads and singletons were removed from the dataset, which was then rarefied to an even sequencing depth of 250 reads (allowing to keep most samples in the analyses). Alpha diversity was analyzed with Shannon and Chao1 diversity indexes along with richness (observed number of ASVs) (Jones et al. 2018). Multivariate statistics for the community composition were performed in R ( $\mathrm{R}$ Development Core Team 2008) and included: analysis of similarity (ANOSIM, 'vegan package' Oksanen et al. 2013; Holloway-Adkins and Hanisak 2017), permutational multivariate analysis of variance (PERMANOVA, 'vegan package' (Oksanen et al. 2013; adonis2; Jones et al. 2018), multivariate homogeneity of group dispersion (PERMDISP; 'vegan package' Oksanen et al. 2013; betadisper; Jones et al. 2018) and non-metric multidimensional scaling (NMDS, 'phyloseq package' McMurdie and Holmes 2013; Holloway-Adkins and Hanisak 2017), all based on Bray-Curtis dissimilarities. Graphs were created in R using ggplot2 (Wickham 2009) and phyloseq (McMurdie and Holmes 2013) packages. Statistical analyses were performed using rarefied data. Filtered data without ASVs that did 
not occur at least one time in $10 \%$ of the samples were used for the multivariate analyses. Estimates are given as average \pm SD unless otherwise specified.

Overall, three different sample types were collected and successfully sequenced for identification of diet items: cloaca $(n=6)$ and esophagus $(n=6)$ swabs from six juvenile green turtles, and intestine samples $(n=3)$ from three dead green turtle hatchlings (see Table S2 for overview). After rarefaction, one sample was discarded (due to low number of reads) leading to a total of $n=5$ cloaca and $n=6$ esophagus samples originating from six juvenile green turtles. This is considered a sufficient sample size for analyses of ecological communities (Anderson et al. 2006). Because there were only three samples for the category "intestines", these were excluded from the statistical analyses.

\section{Benthic community characterization and barcoding of local food items}

To describe local benthic macrophyte composition and compare with the results from the swab samples, we deployed quadrats $(50 \times 50 \mathrm{~cm})$ placed at 30 random points inside the netted area. At each location, all identifiable algae and seagrass taxa inside the quadrat were noted. This procedure was repeated during each sampling session.

To increase the resolution of taxonomic assignments of metabarcoding sequences, locally available organisms putatively used as food items by green turtles (according to their availability found during the benthic community characterization) were obtained during fieldwork and preserved as described for the swab samples. The $18 \mathrm{~S}$ rRNA gene of a subset of these items was sequenced at CCMAR by Sanger sequencing using the same primer used for metabarcoding. This local database was used to assign the dominant metabarcoding reads obtained from the sea turtle samples to regionally common genuslevel taxa macrophytes potentially consumed as food. The sequences were compared against nucleotide databases using blastn (https://blast.ncbi.nlm.nih.gov/Blast. cgi?PAGE_TYPE=BlastSearch), and best matches were ranked based on sequence coverage and \% identity. $18 \mathrm{~S}$ rRNA gene sequences and best blastn hits were aligned using the MUSCLE implementation built into Geneious ( $\mathrm{v}$ 5.6.5), allowing phylogenetic comparisons using maximum likelihood phylogenetic trees built with PHYML and using the HKY 85 substitution model and 1000 bootstraps for determining branch support. Moreover, to increase the resolution of the identification, some of the key local food items (Spyridia sp., Laurencia sp. and Hypnea sp.) were further sequenced for the standard barcoding marker cox1 using GAZ primers (Saunders and McDevit 2012) and blasted against nucleotide databases as for the $18 \mathrm{~S}$ rRNA gene.

\section{Data availability}

Demultiplexed sequences and metadata are available from the NCBI Sequence Read Archives (SRA) under BioProject Accession number PRJNA781615.

\section{Results}

\section{Sampling}

Six juvenile green turtles were sampled in four capture sessions, with body sizes ranging from 36.5 to $48.1 \mathrm{~cm}$ of curved carapace length, with an average of $40.4 \mathrm{~cm} \pm 4.0 \mathrm{~cm}$ $\mathrm{SD}$. For more information on the sampled individuals, see Table S2. Many swabs presented small pieces of seagrass after esophageal swabbing took place, and nearly all swabs led to a change in the fixative color (from clear to brown, orange, gray or yellow green) when plunged into it.

\section{Analysis of metabarcoding data}

A total of 699,971 good-quality reads (i.e., phred $>35$, nonchimeric) were generated from the 15 samples sequenced (Table S3), corresponding to ca. $48 \%$ of the initial number of reads. The samples had an average of $51,128 \pm 12,823$ reads, which clustered into 306 unique ASVs across all samples combined. As expected, due to the eukaryotic-universal coverage of the $18 \mathrm{~S}$ rRNA gene primers, a large proportion of reads corresponded to turtle DNA $(99.8 \pm 0.2 \%$ for intestine samples, $98.7 \pm 1.8 \%$ for cloaca and $59.6 \pm 23.6 \%$ for esophagus, see Fig. S1). These reads were removed from the analyses to focus on the diet.

Overall, alpha diversity differed among the sample types analyzed (i.e., esophagus vs cloaca vs intestine; see Fig. S2). The esophagus sequences contained more diet items $(11 \pm 5$ ASVs per sample) than cloacal ones $(8 \pm 2$ ASVs; $\left.\mathrm{F}_{(1,9)}=9.252, p=0.014\right)$. As expected, intestine samples from hatchlings, used as a methodological control yielded the lowest number of ASVs $(5 \pm 6$, Fig. S2), with a negligible number of reads $(0.2 \%)$ assigned to diet (i.e., nonturtle). These samples were thus not further analyzed for diet content. The food items assemblage identified was differently structured according to the compartment of origin (i.e., esophagus vs cloaca samples) (Fig. 2; PERMANOVA, $\mathrm{F}_{(1,9)}=2.709, p=0.0019$; ANOSIM, $\left.R=0.596, p=0.0032\right)$, despite not differing in multivariate dispersion (PERMDISP, $\left.\mathrm{F}_{(1,9)}=0.757, p=0.4069\right)$. 


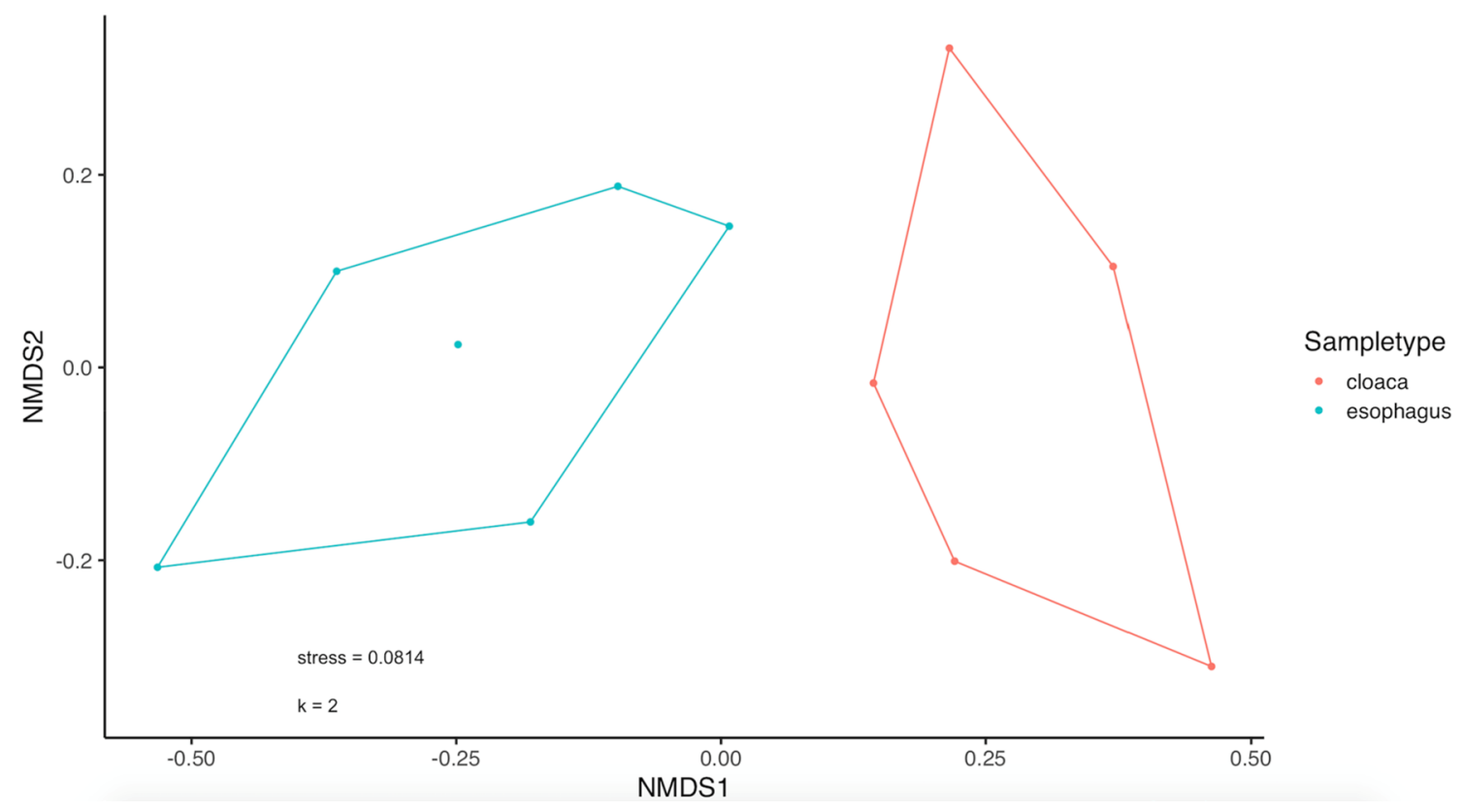

Fig. 2 Community structure of green turtle diet items for cloaca $(n=5)$ and esophagus $(n=6)$ samples. NMDS plot based on Bray-Curtis similarity

\section{Diet characterization}

The main non-chelonian DNA sequences found were red macroalgae, seagrasses, different animal groups and unicellular eukaryotes (Fig. 3). Rhodophyta (red algae) were the predominant food items for both sample types combined (48.2 $\pm 16.3 \%$ of total ASVs), followed by Bacillariophyceae (diatoms) $(7.5 \pm 7.3 \%)$, Cymodoceaceae (seagrass

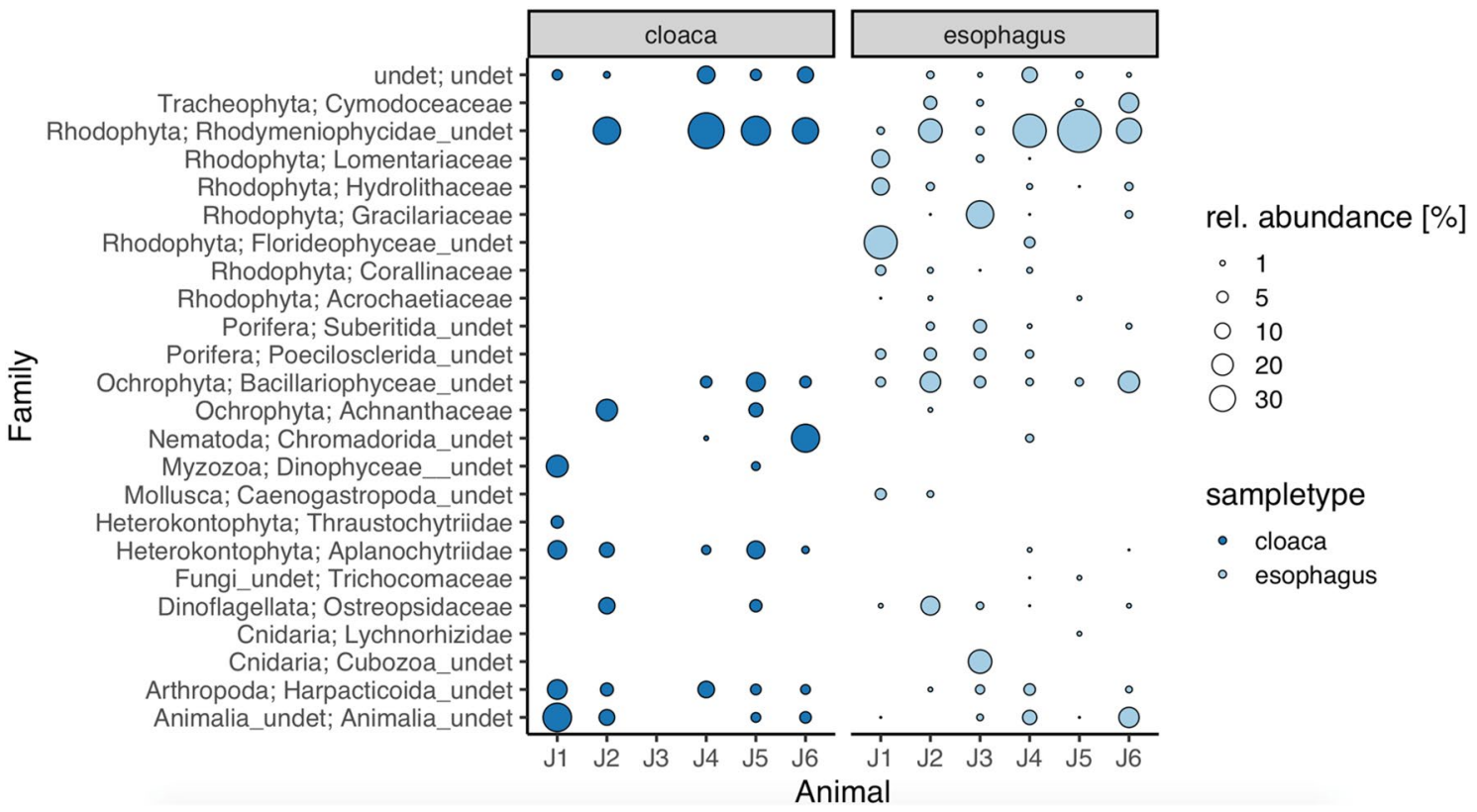

Fig. 3 Diet community composition for cloaca and esophagus of green turtles. Size of bubble plots represents relative abundance of 18S rRNA gene amplicon sequence variants (\%) and diet items are given at the taxonomic levels of phylum and family. When family affiliation was not possible to determine, the lowest identified taxo- nomic rank is shown (followed by "undet"; i.e., undetermined). Only the most abundant diet items are shown. Note that for one cloaca sample (Animal J3), diet data are not shown due to low number of reads and exclusion during rarefaction 
family of which the only local species is Halodule wrightii) $(2.6 \pm 6.8 \%)$ and undetermined groups of animals (undetermined Animalia). The esophagus samples presented higher content of red algae $(32.3 \pm 18.2 \%)$ and seagrasses $(2.6 \pm 6.5 \%)$ than the cloaca, which had a higher content of groups of organisms other than macrophytes, such as protists $(9.8 \pm 6.5 \%)$, crustaceans $(4.2 \pm 5.5 \%)$ and nematodes $(3.6 \pm 16.0 \%)$.

There were differences in specific taxa identified between esophagus and cloaca (see Fig. 3), but also some overlap. For instance, an undetermined family in the Rhodymeniophycidae red algae subclass (Rhodophyta, class Florideophyceae) was the most abundant family $(35.1 \pm 27.2 \%)$ of diet items in both cloacal and esophageal samples, followed by diatoms (Bacillariophyceae; $7.5 \pm 7.3 \%$ ). Another red algal family (undetermined Florideophyceae; Fig. 3) was the second most abundant $(5.4 \pm 15.2 \%)$ food item present in the esophagus, but was absent in the cloaca. The seagrass family Cymodoceaceae (locally Halodule wrightii) was also present in esophageal samples $(2.6 \pm 6.8 \%)$, but missing from the cloacal ones of the same sea turtle individuals. In contrast, an undetermined family in the nematode order Chromadorida was the second most abundant taxa in cloacal samples $(3.6 \pm 16.0 \%)$, and almost absent from the esophagus $(0.2 \pm 1.0 \%)$. Less than $1 \%$ of reads in esophagus and cloaca samples combined corresponded to green $(0.02 \pm 6.51 \%)$ and brown macroalgae $(0.01 \pm 0.00 \%)$.

\section{Benthic community characterization and barcoding of local food items}

Regional benthic macrophyte communities at the turtle sampling site were characterized by a dominance of the seagrass Halodule wrightii (Tracheophyta), and the brown algae (Phaeophyceae), Padina sp. and Sargassum sp., which were present in at least $50 \%$ of the random quadrat points (see Table S4; Fig. 4), followed by red algae. Of these, two species of Rhodymeniophycidae were particularly abundant (frequency of occurrence $>10 \%$ each), Laurencia dendroidea and Spyridia filamentosa (as identified by cox 1 barcoding analyses; results not shown). Grazed patches of seagrass (Halodule sp.) were observed.

The dominant red algae reads found in the esophagus samples clustered closely with $18 \mathrm{~S}$ rRNA gene barcodes generated from local macrophytes (seagrasses and seaweeds) collected in the study site. Matching esophageal

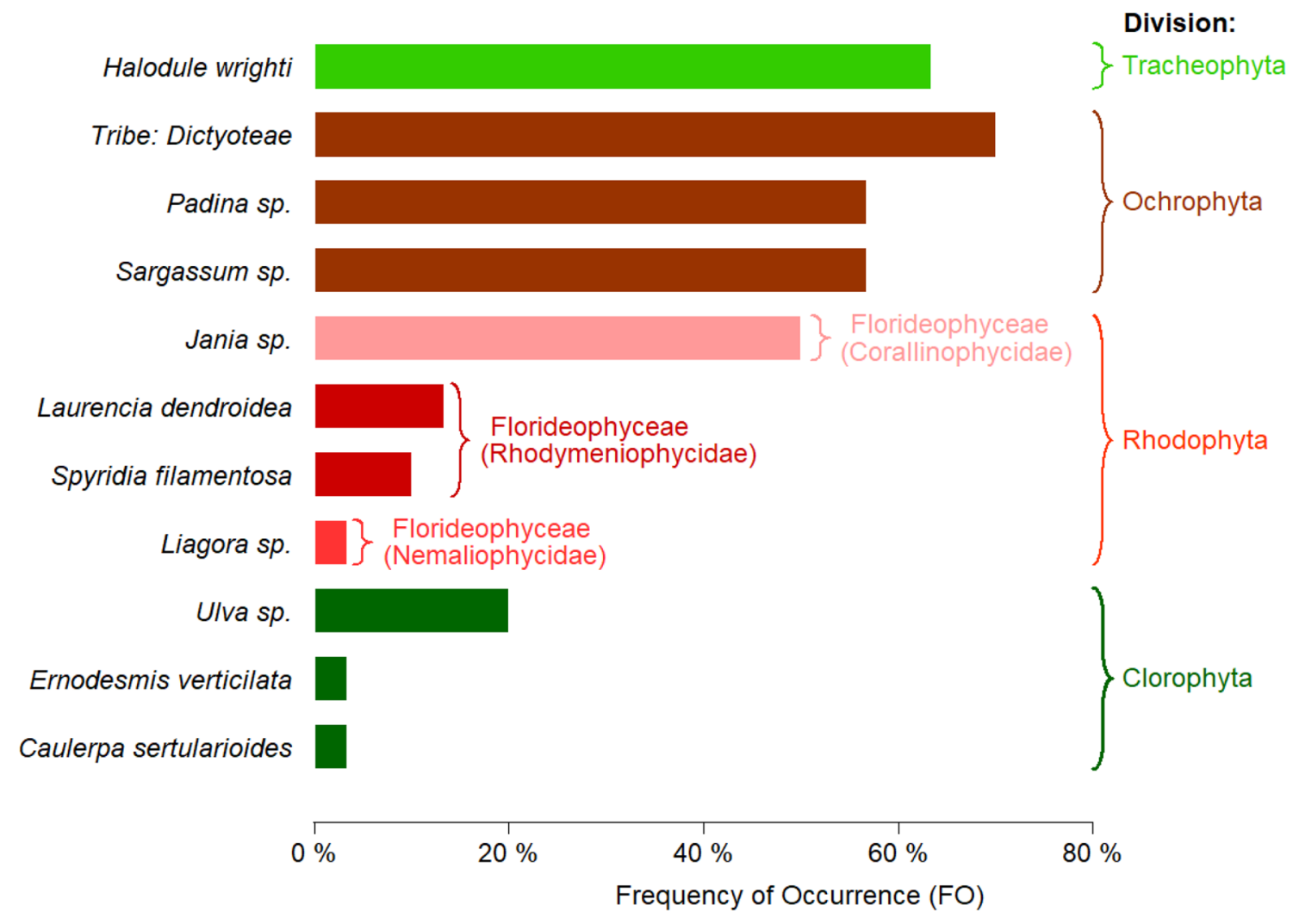

Fig. 4 Frequency of occurrence FO, (in percent) of main macroalgae and seagrass groups found in the sampling area, listed by division. Rhodophyta are further subdivided in Classes (Subclasses). Data were obtained by 30 random $50 \times 50 \mathrm{~cm}$ quadrats per session (two sessions). FO represents the percentage of quadrats for which the taxon was found to be present 


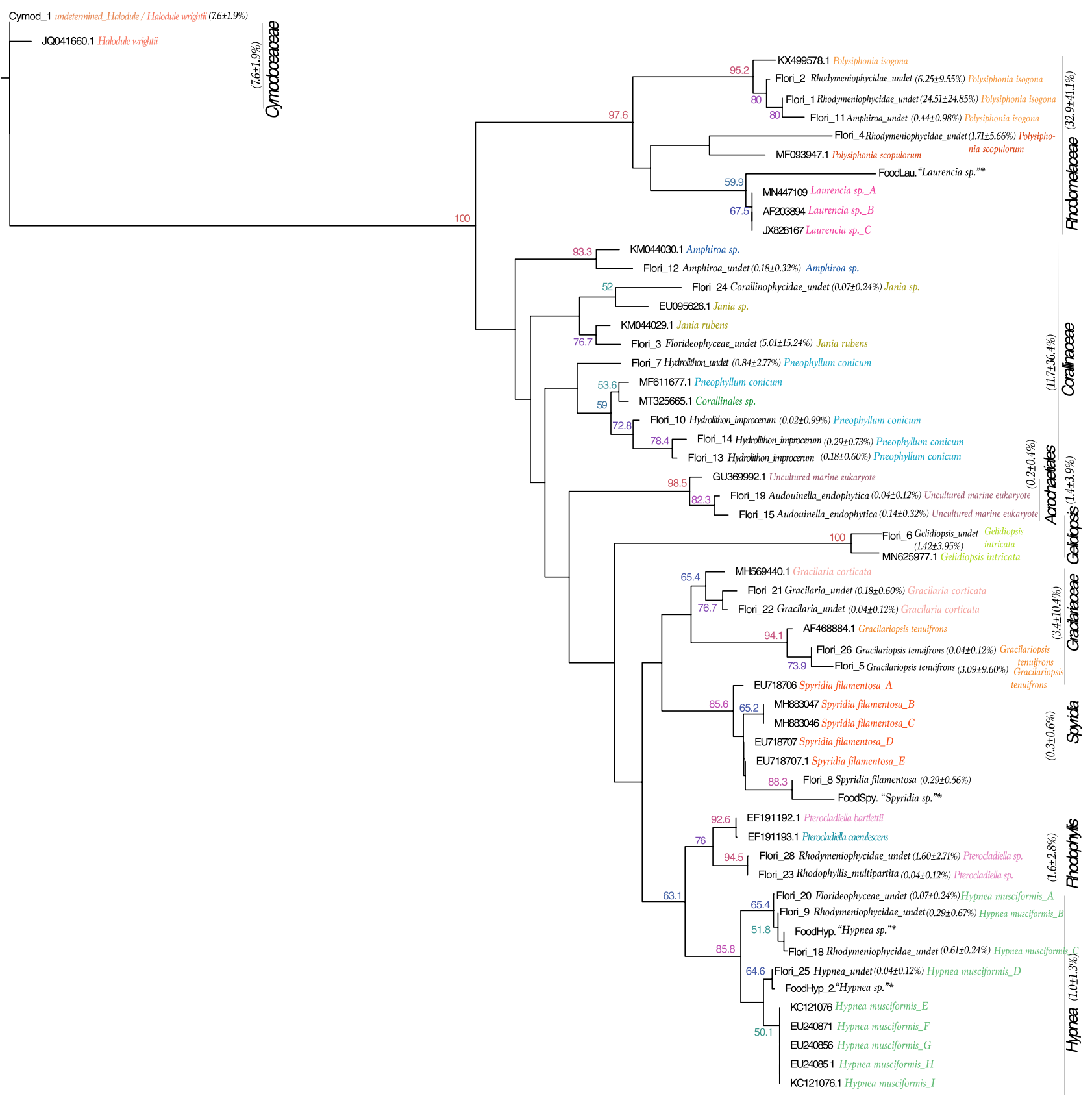

Fig. 5 Phylogenetic tree generated from the 18S rRNA gene metabarcoding of the local macrophytes. Esophageal reads belonging to the dominant red algae Rhodymeniophycidae subclass ASVs are represented as (Flori_X) and named following the results of the phylogenetic analysis down to species level (black labels); next to them, the relative abundance in the esophagus is shown as mean percentage and standard deviation. Close relatives of the (Flori_X) sequences according to NCBI are displayed as accession numbers. The ID given by Blast (color labels) to the lowest taxonomic level appears next to the accession numbers and after the relative abundances for each ASV (Flori_X). Items with an asterisk (*) correspond to the barcoded local prey items found during the surveys (name between quotes as given by the collector in the field). Vertical labels give higher taxonomic levels and relative abundances. The outgroup corresponds to the only seagrass ASV in the analysis, identified as Halodule_undet (i.e., undetermined) (Tracheophyta: Cymodoceaceae in Fig. 3). Bootstrap values $<50 \%$ not shown 
reads (named as FloriX in Fig. 5) were closely related to Polysiphonia sp., Laurencia sp. and Hypnea sp. (Fig. 5). Nevertheless, calcareous coralline algae (order Corallinalles; such as Jania sp.) were also commonly ingested, as many of the esophageal reads clustered within this group of algae (Fig. 5). Most abundant ASVs closely matched Polysiphonia sp. (undetermined Rhodymeniophycidae, $24.5 \pm 24.8 \%$; undetermined Rhodymeniophycidae, $6.2 \pm 9.6 \%$ ) and Jania rubens (undetermined Florideophyceae, $5.0 \pm 15.2 \%)$.

\section{Discussion}

The diet identification method here tested, based on metabarcoding of esophagus and cloaca swabs of green turtles with the 18S rRNA gene, allowed the identification, at acceptable taxonomic resolution, of food items of green turtle diets. We consider that this method can be widely applied for sea turtle diet assessments, with higher resolution and lower invasiveness than previously available methods. Red algae, seagrasses and diatoms were the most dominant sequenced taxa in samples from six juvenile green turtles captured in Guinea-Bissau. Ingestion of red algae and seagrasses was corroborated by field observations. First, three turtles were observed locally with pieces of seagrass (Halodule sp.) in their mouth and three others exhibited red saliva, likely related to the ingestion of red algae. Second, grazed patches of seagrass (Halodule sp.) were observed (Madeira, pers. obs.). Finally, a necropsy of a juvenile individual showed that most of its stomach contents were red algae, identified as Laurencia dendroidea; nevertheless, small quantities of Halodule sp., Dictyota sp. and Caulerpa sp. were also present. These observations support the metabarcoding results suggesting the ingestion of red algae and seagrasses and highlight the efficacy of the method used in this study.

Rhodophyta were the most abundant items in turtle diet, particularly red algae in the Rhodymeniophycidae subclass. Our attempts to narrow down the taxonomic identification of the red algae by using a barcoding approach of local items (using $18 \mathrm{~S}$, complemented by $\operatorname{cox} 1$ ) allowed to identify tissue samples of Polysiphonia isogona, Laurencia sp. and Hypnea sp. as the main diet items of green sea turtles in these sampling locations. Although in low abundance, Halodule sp. was also found in the metabarcoding analysis, exclusively in esophagus samples. The presence of the red algae Polysiphonia isogona as the most abundant diet item (most abundant ASV, $24.5 \pm 24.8 \%$ ) corroborates previous published information, as Polysiphonia spp. have been shown to be components of green turtle diet, along with a variety of red and green algae (Spotila 2004).
Despite field observations of dominance of brown algae in the benthos, particularly Dictyotales and Sargassum sp., these taxa were barely identified in the analyses of the turtle digestive tracts (less than $1 \%$ of reads corresponded to brown macroalgae). This result suggests the hypothesis of feeding preferences of green turtles for the less abundant red algae over the locally dominant brown algae. An additional hypothesis is that the turtles might have been feeding on other grounds more dominated by red algae, which still support the hypothesis of food preference for red algae. Two red algal species of Rhodymeniophycidae were nevertheless particularly frequent $(>10 \%$ each) at the sampling site, Laurencia dendroidea and Spyridia filamentosa. These are the two dominant red algal species of the marine forests of most islands of Bijagós, and in other surveyed sites of this archipelago they reach $>90 \%$ cover (unpublished data).

The high abundance of diatoms in both the cloaca and esophagus likely reflects passive ingestion explained by their previously described epiphytic lifestyle on seagrasses such as Halodule sp. (Morgan and Kitting 1984; Dawes and Walter 2010). This is also likely the case for the calcareous coralline algae found in the diet (James et al. 2009; Martin et al. 2008; Perry and Beavington-Penney 2005), despite previous reports that epiphytic coralline algae may prevent overgrazing of seagrass (Leemans et al. 2020). Moreover, other organisms such as foraminifera, ciliates, and other benthic animals found in the analysis are likely present in the diet because they are also epiphytes of seagrass and seaweed (Langer 1993; Larkum et al. 2006), and not necessarily because of targeted consumption.

Differences observed between cloacal- and esophagealderived diet composition are most likely to be due to digestion. The higher content of red algae and seagrass in the esophagus and not in the cloaca suggests that green turtles digest and absorb effectively these food resources (Bjorndal 1980). On the contrary, the presence of items different from algae and seagrass in the cloaca, such as crustaceans and protists, could be interpreted as items harder to digest or as parasites or symbionts of the cloaca, a body region more prone to such colonization by external taxa than the esophagus. Finally, elements present in both the esophagus and cloaca could hypothetically represent non-digestible items. Overall, these findings indicate that the esophagus is likely the preferred compartment for the diet characterization of sea turtles. However, to fully validate this conclusion, future studies will be needed including a larger number of samples as well as a broader time window that is able to cover diel variation of ingested items.

The intestine samples from hatchlings proved a good control of the method. The samples yielded a very low number of non-chelonian 18S rRNA gene reads, as expected from the absence of feeding by sea turtle hatchlings in their first 
days of life (Smith and Daniel 1946; Hughes 1974). Notably, one of the intestine samples showed a scarce presence of the pathogenic yeast Malassezia pachydermatis, which is likely the result of post-mortem infection. The high number of turtle reads obtained from cloaca and esophagus samples indicates that the protocol could still be enhanced to obtain a larger relative proportion of sequences from the diet items, for instance, using turtle DNA blocking primers.

A diet composition similar to the one we describe here was found (via esophageal lavages) in green turtles from southern Brazil (Reisser et al. 2013), dominated by red macroalgae Pterocladiella capillacea. Dominance of red algae in green turtle diets has also been described for the East Coast of Florida (Holloway-Adkins 2001) and in Bahía de los Angeles in the Gulf of California, in Mexico, with Gracilariopsis lemaneiformis being the most abundant species (Seminoff et al. 2002). Gracilariopsis sp. was also the main food item of green turtles from Flathead Gutter, Moreton Bay in south-east Queensland, Australia (Brand-Gardner et al. 1999). Taken together, these studies suggest that red algae are a recurrent food item despite large spatial variability regarding the most locally consumed species (probably related to availability).

Although we found the diet to be almost exclusively herbivorous, therefore corroborating previous evidence (Seminoff et al. 2002; Fuentes et al. 2006; Stokes et al. 2019), we also identified other diet components such as nematodes, sponges, corals, molluscs, annelids and even crustaceans. These might be invertebrates found in the seaweed and seagrass eaten by the turtles. A similar mixture of diverse diet items of green turtles has been previously found in Eastern Pacific green turtles in Colombia with presence of tunicates (Salpidae and Doliolidae), red mangrove fruits, algae (Rhodophyta, Chlorophyta, Cyanophyta), small crustaceans (shrimp larvae) and plant leaves (Amarocho and Reina 2007). This mixture of diverse prey, especially invertebrates, could be beneficial as nitrogen supplement (Forbes 1996).

Taxonomic assignment of turtle diet items, as assessed with $18 \mathrm{~S}$ rRNA gene metabarcoding, is limited by the absence of a local database for turtle food items from Guinea-Bissau. We used the best database available (SILVA, see methods section), but the capacity to identify diet items could still be improved with a larger local database than the one created here. Barcoding of tissue samples of local Caulerpa sp. and Jania sp. yielded foraminifera and ciliate sequences, respectively, which indicates that some of these animals are likely present as epibionts of targeted food items. Importantly, the diet results presented in this manuscript only provide a single-site snapshot of what the animals had eaten in recent feeding events. For comprehensive assessments of the diet of foraging aggregations, samples should be collected at different periods in time, encompassing any existing seasonal variations.
We conclude that our minimally invasive metabarcoding method, preferentially based on esophagus swabs (rather than cloacal swabs), is suitable and a promising alternative to other more intrusive techniques. A direct comparison to other techniques is warranted to evaluate the performance of eDNA metabarcoding approach with respect to other available methods. Control studies with experimentally fed animals and/or targeting multiple foraging grounds dominated by distinct macrophyte communities (seagrass, brown or red algae) are also natural next steps to further evaluate the strengths of this promising approach. Additionally, we have contributed to the scarce information about green turtle feeding preferences in Guinea-Bissau, by establishing a baseline for the diet of this foraging aggregation. Diet characterization combined with foraging ecology studies can help conservation managers to identify critical habitats in need of long-term protection and enable a better understanding of foraging hotspots and regional connectivity (Stokes et al. 2019). Our findings, corroborated by field observations, validate esophagus swab metabarcoding to accurately characterize the diet of green turtles. This method is less intrusive compared to traditional esophageal lavage, reduces animal handling, and is also easily reproducible. Thus, we consider it to be of general application to assess the diet of green turtles and we propose that future studies should explore the utility of this technique with other sea turtle species.

Supplementary Information The online version contains supplementary material available at https://doi.org/10.1007/s00227-021-04002-x.

Acknowledgements Research permits and logistic support in GuineaBissau were provided by the Instituto da Biodiversidade e das Áreas Protegidas Dr. Alfredo Simão da Silva (IBAP). Fieldwork was conducted in collaboration with IBAP staff members and with the local communities of the Bijagós, to whom we are deeply thankful. Also supported by MAVA (PNBA-site emblématique pour les tortues) and PRCM/STM POOOA4/OA9.

Author contributions NBM, ARP, EAS and PRF conceived and designed the experiments; NBM and FM collected turtle swabs; NBM and PRF performed molecular work; TA, JN and FM barcoded diet groups. LDA and PRF analyzed the data and prepared figures and tables; LDA wrote a first draft of the manuscript. All authors contributed to and approved the final version of manuscript.

Funding Metabarcoding analyses were funded by the FCT-Science and Technology Foundation of Portugal (UIDB/04326/2020) and a Pew Marine Fellowship to EAS and Tropibio Era Chair (EU grant 854248 and NORTE-01-0145-FEDER-000046). FCT funded fellowships to PRF (SFRH/BDP/110285/2015), EAS (SFRH/BSAB/150485/2019), TA (SFRH/BPD/116774/2016) and contract DL57/2016/CP1361/ CT0010 to JN. ARP was funded by Fundación La Caixa, project 'TurtleResC - sea turtle resilience to climate change impacts' and FCT (UIDB/04292/2020 and UIDP/04292/2020) awarded to MARE. Fieldwork was funded by the project "Consolidation of sea turtle conservation at the Bijagós Archipelago, Guinea-Bissau", awarded to IBAP by 
the MAVA Foundation. The funders had no role in the study designing, data collection and analysis, decision to publish, or preparation of the manuscript.

Data availability Demultiplexed sequences and metadata are available from the NCBI Sequence Read Archives (SRA) under BioProject Accession number PRJNA781615.

\section{Declarations}

Conflict of interest The authors declare no competing interests.

Ethical approval Research permits were provided by the National Governmental Institute for Biodiversity Conservation, the 'Instituto da Biodiversidade e das Áreas Protegidas, Dr. Alfredo Simão da Silva (IBAP-Guinea-Bissau)'. Sampling procedures were carried out by trained personnel following recommended guidelines (NMFS-SFC 2008), to reduce stress to the animals and improve their welfare.

Open Access This article is licensed under a Creative Commons Attribution 4.0 International License, which permits use, sharing, adaptation, distribution and reproduction in any medium or format, as long as you give appropriate credit to the original author(s) and the source, provide a link to the Creative Commons licence, and indicate if changes were made. The images or other third party material in this article are included in the article's Creative Commons licence, unless indicated otherwise in a credit line to the material. If material is not included in the article's Creative Commons licence and your intended use is not permitted by statutory regulation or exceeds the permitted use, you will need to obtain permission directly from the copyright holder. To view a copy of this licence, visit http://creativecommons.org/licenses/by/4.0/.

\section{References}

Albaina A, Aguirre M, Abad D, Santos M, Estonba A (2016) 18S rRNA V9 metabarcoding for diet characterization: a critical evaluation with two sympatric zooplanktivorous fish species. Ecol Evol 6(6):1809-1824. https://doi.org/10.1002/ece3.1986

Amarocho DF, Reina RD (2007) Feeding ecology of the East Pacific green sea turtle Chelonia mydas agassizii at Gorgona National Park, Colombia. Endanger Spec Res 3:43-51. https://doi.org/ 10.3354/esr003043

Anderson MJ, Ellingsen KE, McArdle BH (2006) Multivariate dispersion as a measure of beta diversity. Ecol Lett 9(6):683-693

André J, Gyuris E, Lawler IR (2005) Comparison of the diets of sympatric dugongs and green turtles on the Orman Reefs, Torres Strait, Australia. Wildl Res 32:53-62. https://doi.org/10. 1071/WR04015

Arizza V, Vecchioni L, Caracappa S, Sciurba G, Berlinghieri F, Gentile A et al (2019) New insights into the gut microbiome in loggerhead sea turtles Caretta caretta stranded on the Mediterranean coast. PLoS ONE 14(8):e0220329

Arthur KE, Boyle MC, Limpus CJ (2008) Ontogenetic changes in diet and habitat use in green sea turtle (Chelonia mydas) life history. Mar Ecol Prog Ser 362:303311. https://doi.org/10.3354/meps0 7440

Bjorndal KA (1980) Nutrition and grazing behaviour of the green turtle, Chelonia mydas. Mar Biol 56:147-154

Bjorndal KA (1997) Foraging ecology and nutritional ecology of sea turtles. In: Lutz P, Musick JA (eds) Biology of the sea turtles. CRC Press, Boca Raton, pp 237-283
Bodawatta KH, Puzejova K, Sam K et al (2020) Cloacal swabs and alcohol bird specimens are good proxies for compositional analyses of gut microbial communities of Great tits (Parus major). Anim Microb. https://doi.org/10.1186/s42523-020-00026-8

Bolyen E, Rideout JR, Dillon MR, Caporaso JG (2019) Reproducible, interactive, scalable and extensible microbiome data science using QIIME 2. Nat Biotechn 37:852-857. https://doi.org/10.1038/ s41587-019-0209-9

Brand-Gardner SJ, Limpus CJ, Lanyon JM (1999) Diet selection by immature green turtles, Chelonia mydas, in subtropical Moreton Bay, south-east Queensland. Austral J Zool 47:181-191

Brandis R, Mortimer J, Reilly B, van Soest R, Branch G (2014) Diet Composition of hawksbill turtles (Eretmochelys imbricata) in the Republic of Seychelles. West Indian Ocean J Mar Sci 13:81-91

Bremner J (2008) Species' traits and ecological functioning in marine conservation and management. J Exp Mar Biol Ecol 366(1-2):37-47

Burkholder DA, Heithaus MR, Thomson JA, Fourqurean JW (2011) Diversity in trophic interactions of green sea turtles Chelonia mydas on a relatively pristine coastal foraging ground. Mar Ecol Prog Ser 439:277-293. https://doi.org/10.3354/meps09313

Callahan BJ et al (2016) DADA2: high-resolution sample inference from Illumina amplicon data. Nat Methods 13:581

Carr A (1987) New perspectives on the pelagic stage of sea turtle development. Conserv Biol 1:103-121. https://doi.org/10.1111/j. 1523-1739.1987.tb00020.x

Casale P, Heppell SS (2016) How much sea turtle bycatch is too much? A stationary age distribution model for simulating population abundance and potential biological removal in the Mediterranean. Endager Spec Res 29(3):239-254

Dawes C, Walter A (2010) Epiphytes of the seagrass Halodule wrightii in Hillsborough Bay, Florida; a 14-year study in an estuary recovering from eutrophication. Fla Sci 73:185-195

Forbes GA (1996) The diet and feeding ecology of the green sea turtle (Chelonia mydas) in an algal-based coral reef community. $\mathrm{PhD}$ thesis, James Cook Univeristy

Fuentes MPB, Lawler IR, Gyuris E (2006) Dietary preferences of juvenile green turtles (Chelonia mydas) on a tropical reef flat. Wildl Res 33:671-678

Gannes LZ, Martínez del Rio C, Koch P (1997) Stable isotopes in animal ecology: assumptions, caveats, and a call for more laboratory experiments. Ecology 78:1271-1276

Godley BJ, Broderick AC, Colman LP, Formia A, Godfrey MH, Hamann M, Shanker K (2020) Reflections on sea turtle conservation. Oryx 54(3):287-289

Guardiola M, Uriz MJ, Taberlet P, Coissac E, Wangensteen OS, Turon X (2015) Deep-sea, deep-sequencing: metabarcoding extracellular DNA from sediments of marine canyons. PLoS ONE 10(10):e0139633. https://doi.org/10.1371/journal.pone.0139633

Hamann M, Godfrey MH, Seminoff JA, Arthur K, Barata PCR, Bjorndal KA, Bolten AB, Broderick AC, Campbell LM, Carreras C, Casale P, Chaloupka M, Chan SKF, Coyne MS, Crowder LB, Diez CE, Dutton PH, Epperly SP, Fitzsimmons NN, Formia A, Girondot M, Hays GC, Cheng IJ, Kaska Y, Lewinson R, Mortimer JA, Nichols WJ, Reina RD, Shanker K, Spotila JR, Tomás J, Wallace BP, Work TM, Zbinden J, Godley BJ (2010) Global research priorities for sea turtles: informing management and conservation in the 21st Century. Endanger Spec Res 11:245-269

Hazel J, Hamann M, Lawler IR (2013) Home range of immature green turtles tracted at an offshore tropical reef using automated passive acoustic technology. Mar Biol 160:617-627. https://doi.org/10. 1007/s00227-012-2117-0

Holloway-Adkins KG (2001) A comparative study of the feeding ecology of Chelonia mydas (green turtle) and the incidental ingestion of Prorocentrum sp. Retrospective Theses and Dissertations. p. 1207 
Holloway-Adkins KG, Hanisak MD (2017) Macroalgal foraging preferences of juvenile green turtles (Chelonia mydas) in a warm temperate/subtropical transition zone. Mar Biol 164:161. https://doi. org/10.1007/s00227-017-3191-0

Howell LN, Shaver DJ (2021) Foraging Habits of Green Sea Turtles (Chelonia mydas) in the Northwestern Gulf of Mexico. Front Mar Sci 8:658368. https://doi.org/10.3389/fmars.2021.658368

Howell LN, Reich KJ, Shaver DJ, Landry AM Jr, Gorga CC (2016) Ontogenetic shifts in diet and habitat of juvenile green sea turtles in the northwestern Gulf of Mexico. Mar Ecol Prog Ser 559:217229. https://doi.org/10.3354/meps 11897

Hughes GR (1974) The sea turtles of south-east Africa. II. The biology of the Tongaland loggerhead turtle Caretta caretta L. with comments on the leatherback turtle Dermochelys coriacea L. and the green turtle Chelonia mydas $\mathrm{L}$. in the study region. Oceanogr Res Inst Invest Rep 36:96

James NP, Bone Y, Brown KM, Cheshire A (2009) Calcareous epiphyte production in cool-water carbonate seagrass depositional environments—-southern Australia. In: Swart PK, Eberli GP, McKenzie JA, Jarvis I, Stevens T (eds) Perspectives in carbonate geology: a tribute to the career of Robert Nathan Ginsburg, vol 41. IAS Special Publication, Kolkata, pp 123-148

Jones J, DiBattista JD, Stat M, Bunce M, Boyce MC, Fairclough DV, Travers MJ, Huggett MJ (2018) The microbiome of the gastrointestinal tract of a range-shifting marine herbivorous. Fish Front Microbiol 9:2000. https://doi.org/10.3389/fmicb.2018.02000

Langer M (1993) Epiphytic Foraminifera. Mar Micropaleontol 20:235265. https://doi.org/10.1016/0377-8398(93)90035-V

Larkum AWD, Orth RJ, Duarte CM (2006) Seagrasses: biology, ecology and conservation. Springer, Berlin

Leemans L, Martínez I, van der Heide T et al (2020) A mutualism between unattached coralline algae and seagrasses prevents overgrazing by sea turtles. Ecosystem 23:1631-1642. https://doi.org/ 10.1007/s10021-020-00492-w

Legler JM (1976) Feeding habits of some Australian short-necked tortoises. Vic Nat 93:40-43

Legler JM (1977) Stomach flushing: a technique for chelonian dietary studies. Herpetology 33(3):281-284

Levey DJ, Martinez del Rio C (2001) It takes guts (and more) to eat fruit: lessons from avian nutritional ecology. Auk 118:819-831

Martin S, Rodolfo-Metalpa R, Ransome E, Rowley S, Buia MC, Gattuso JP, Hall-Spencer J (2008) Effects of naturally acidified seawater on seagrass calcareous epibionts. Biol Lett 4:689-692. https:// doi.org/10.1098/rsbl.2008.0412

Mazaris AD, Schofield G, Gkazinou C, Almpanidou V, Hays GC (2017) Global sea turtle conservation successes. Sci Adv 3(9):e1600730

McMurdie PJ, Holmes S (2013) phyloseq: a R package for reproducible interactive analysis and graphics of microbiome census data. PLoS ONE 8:e61217

Morgan MD, Kitting CL (1984) Productivity and utilization of the seagrass Halodule wrightii and its attached epiphytes 1. Limnol Oceanogr 29(5):066-107

Mortimer JA (1981) The feeding ecology of the west Caribbean green turtle (Chelonia mydas) in Nicaragua. Biotropica 13:49-58. https://doi.org/10.2307/2387870

National Marine Fisheries Service Southeast Fisheries Center (2008) Sea Turtle Research Techniques Manual. NOAA Technical Memorandum NMFS-SEFSC-579, p. 92

Nelms SE, Duncan EM, Broderick AC, Galloway TS, Godfrey MH, Hamann M, Godley BJ (2016) Plastic and marine turtles: a review and call for research. ICES J Mar Sci 73(2):165-181

Oksanen J et al (2013) vegan: community ecology package. R package version 2:0-9

Ortega A, Geraldi NR, Díaz-Rúa R, Ørberg SB, Wesselmann M, Krause-Jensen D, Duarte CM (2020) A DNA mini-barcode for marine macrophytes. Mol Ecol Resour 20(4):920-935. https:// doi.org/10.1111/1755-0998.13164

Patrício AR, Varela MR, Barbosa C, Broderick AC, Catry P, Hawkes LA, Regalla A, Godley BJ (2019) Climate change resilience of a globally important sea turtle nesting population. Glob Change Biol 25(2):522-535

Patrício AR, Hawkes LA, Monsinjon JR, Godley BJ, Fuentes MM (2021) Climate change and marine turtles: recent advances and future directions. Endanger Spec Res 44:363-395

Perry CT, Beavington-Penney SJ (2005) Epiphytic calcium carbonate production and facies development within sub-tropical seagrass beds, Inhaca Island. Mozamb Sediment Geol 174:161-176. https://doi.org/10.1016/j.sedgeo.2004.12.003

Post DM (2002) Using stable isotopes to estimate trophic position: models, methods and assumptions. Ecology 83:703-718

Quast C, Pruesse E, Yilmaz P, Gerken J, Schweer T, Yarza P, Peplies J, Glöckner FO (2013) The SILVA ribosomal RNA gene database project: improved data processing and web-based tools. Nucl Acids Res 41(D1):D590-D596

R Development Core Team (2008) R: a language and environment for statistical computing. R Foundation for Statistical Computing

Reisser J, Proietti M, Sazima I et al (2013) Feeding ecology of the green turtle (Chelonia mydas) at rocky reefs in western South Atlantic. Mar Biol 160:3169-3179. https://doi.org/10.1007/ s00227-013-2304-7

Santidrián-Tomillo P, Roberts SA, Hernández R, Spotila JR, Paladino FV (2015) Nesting ecology of East Pacific green turtles at Playa Cabuyal, Gulf of Papagayo, Costa Rica. Mar Ecol 36(3):506-516

Saunders GW, McDevit DC (2012) Methods for DNA barcoding photosynthetic protists emphasizing the macroalgae and diatoms. Methods Mol Biol 858:207-222. https://doi.org/10.1007/978-161779-591-6_10

Seminoff JA, Resendiz A, Nichols WJ (2002) Diet of East Pacific green turtles (Chelonia mydas) in the central Gulf of California, Mexico. J Herpetol 36:447-453

Seminoff JA, Jones TT, Eguchi T, Jones DR, Dutton PH (2006) Stable isotope discrimination $\left(\delta^{13} \mathrm{C}\right.$ and $\left.\delta^{13} \mathrm{~N}\right)$ between soft tissues of the green sea turtle Chelonia mydas and its diet. Mar Ecol Prog Ser 308:271-278

Shimada T, Aoki S, Kameda K, Hazel J, Reich K, Kamezaki N (2014) Site fidelity, ontogenetic shift and diet composition of green turtles Chelonia mydas in Japan inferred from stable isotope analysis. Endang Spec Res 25:151-164. https://doi.org/10.3354/esr00616

Smith KU, Daniel RS (1946) Observations of behavioural development in the loggerhead turtle (Caretta caretta). Sci (washington DC) 104:154-156

Spotila J (2004) Sea turtles: a complete guide to their biology, behavior, and conservation. Johns Hopkins University Press, Baltimore

Stokes HJ, Mortimer JA, Hays GC et al (2019) Green turtle diet is dominated by seagrass in the Western Indian Ocean except amongst gravid females. Mar Biol 166:135. https://doi.org/10. 1007/s00227-019-3584-3

Summers TM, Martin SL, Hapdei JR, Ruak JK, Jones TT (2018) Endangered green turtles (Chelonia mydas) of the Northern Mariana Islands: nesting ecology, poaching, and climate concerns. Front Mar Sci 4:428

Taberlet P, Coissac E, Pompanon F, Brochmann C, Willerslev E (2012) Towards next-generation biodiversity assessment using DNA metabarcoding. Mol Ecol 21:2045-2050. https://doi.org/ 10.1111/j.1365-294X.2012.05470.X

Wallace BP, DiMatteo AD, Bolten AB, Chaloupka MY, Hutchinson BJ, Abreu-Grobois FA, Mortimer JA, Seminoff JA, Amorocho D, Bjorndal KA, Bourjea J (2011) Global conservation priorities for marine turtles. PLoS ONE 6(9):e24510

Wickham H (2009) ggplot2: elegant graphics for data analysis. Springer, New York 
Williams T, Athrey G (2020) Cloacal swabs are unreliable sources for estimating lower gastro-intestinal tract microbiota membership and structure in broiler chickens. Microorganism 8:718

Williams N, Bjorndal K, Lamont M, Carthy R (2013) Winter diets of immature green turtles (Chelonia mydas) on a northern feeding ground: integrating stomach contents and stable isotope analyses. Estuar Coast. https://doi.org/10.1007/s12237-013-9741-x

Zhang G, Chain F, Abbott C, Cristescu M (2018) Metabarcoding using multiplexed markers increases species detection in complex zooplankton communities. Evol Appl 11:1901-1914. https://doi. org/10.1111/eva.12694

Publisher's Note Springer Nature remains neutral with regard to jurisdictional claims in published maps and institutional affiliations. 